\title{
Balancing the Interests of Justice: The Case of Afghanistan in The International Criminal Court (ICC)
}

\author{
Siti Rochmah Aga Desyana*, Diajeng Wulan Christianti ${ }^{* *}$, \\ Chloryne Trie Isana Dewi ${ }^{* * *}$ \\ DOI: https://doi.org/10.22304/pjih.v8n1.a6
}

Submitted: January 4, 2021 | Accepted: April 5, 2021

\begin{abstract}
The interests of justice are criteria of the requirements under Article 53 of the Rome Statute to open a formal investigation of a case. However, it can be misinterpreted due to its lack of clear scopes and standards. The Afghanistan case highlighted this obscurity when The Pre-Trial Chamber (PTC) decided that the case should not proceed due to the interests of justice despite lacking negative determination from the Prosecutor, and the Appeals Chamber (AC) overturned this decision by excluding the interests of justice from proprio motu cases. This article verifies the limitations of the criteria in international criminal law (ICL) through the interpretation of the Rome Statute. In addition, it includes the other ICC's supporting documents and the application to previous cases. This study is of the position that, in the Afghanistan decision, the PTC had overstepped their authority and made an arbitrary decision. The AC had misinterpreted the conjunction between Article 53(3) and Article 15(4) by excluding requirements under Article 53 from proprio motu cases. Based on the opinion, the interpretation on the interests of justice to ensure the criteria still valid as a balancing mechanism under the Rome Statute is very urgent.
\end{abstract}

Keyword: Afghanistan, interests of justice, Rome Statute.

\section{Menyeimbangkan Kepentingan Keadilan: Studi Putusan Pra-Peradilan dan Banding Mahkamah Pidana Internasional untuk Kasus Afghanistan}

\begin{abstract}
Abstrak
Kepentingan keadilan adalah salah satu kriteria dalam Pasal 53 Statuta Roma tentang pembukaan penyidikan kasus. Akan tetapi, kriteria ini sangat mungkin untuk disalahgunakan karena kurangnya kejelasan akan cakupan dan standarnya. Kasus Afghanistan adalah contoh hasil produk dari ketidakjelasan ini. Kamar pra-Peradilan (KPP) memutuskan untuk tidak melanjutkan kasus ini karena melawan kepentingan keadilan meskipun Jaksa menyatakan bahwa kepentingan keadilan telah terpenuhi. Kemudian,
\end{abstract}

PADJADJARAN Journal of Law Volume 8 Number 1 Year 2021 [ISSN 2460-1543] [e-ISSN 2442-9325]

* Undergraduate Student at the Faculty of Law, Universitas Padjadjaran, Jl. Dipati Ukur No. 35, Bandung, desyanarachmaaa@gmail.com.

** Lecturer of the Department of International Law, the Faculty of Law, Universitas Padjadjaran, Jl. Dipati Ukur No. 35, Bandung, Dr., S.H. (Universitas Padjadjaran), LL.M. (Univeristy of Geneva, wulan.christianti@unpad.ac.id.

*** Lecturer of the Department of International Law, the Faculty of Law, Universitas Padjadjaran, JI. Dipati Ukur No. 35, Bandung, S.H. (Universitas Padjadjaran), LL.M. (University of Nottingham), chlorine.dewi@unpad.ac.id. 
Kamar Banding (KB) membatalkan putusan tersebut dengan menyatakan bahwa kepentingan keadilan dalam Pasal 53 tidak seharusnya dipertimbangkan dalam kasus proprio motu. Tulisan ini menganalisis batasan dari kepentingan keadilan dalam hukum pidana internasional dengan mengkaji keberadaannya di hukum domestik dan perspektif Mahkamah Pidana Internasional dalam memaknainya. Melalui kajian ini, ditemukan bahwa KPP telah melangkahi kewenangan mereka dan membuat keputusan tak berdasar pada kasus Afghanistan, dan KB salah memaknai hubungan antara Pasal 53(1) dan Pasal 15(4) Statuta Roma dalam putusannya. Karena pentingnya kriteria kepentingan keadilan, penting untuk segera memberikan penafsiran yang baku agar kriteria tersebut dapat digunakan tanpa melanggar Statuta Roma.

Kata kunci: Afghanistan, kepentingan keadilan, Statuta Roma.

\section{A. Introduction}

The PTC concluded that the Afghanistan case investigation would be against the interests of justice. It rejected the prosecutor's request to investigate the case, despite the fact that the prosecutor did not reach a negative determination regarding the criteria in the case submission. The prosecutor then appealed to the AC, which granted the appeal. However, the AC barely addressed the substantial matters regarding the perspective, scope, and authorities for the Interests of Justice in Article 53 of the Rome Statute. Instead, they focus on procedural aspects by excluding the criteria in Article 53(1)-including the interests of justice-from the elements that must be assessed in proprio motu cases. This contrasts with previous assessments of similar matters, and is accused to have political motives. ${ }^{1}$ Into the bargain, the two decisions were possible due to the vagueness and leniency surrounding the interests of justice criteria.

The Rome Statute designs the interests of justice as a balancing mechanism to initiate investigation. The interests of justice should be considered after establishing the matters of jurisdiction and admissibility. It is only mandatory to be raised by the prosecutor following a negative determination of such criteria, which is an exceptional circumstance. ${ }^{2}$ This is able to countervail the positive determinations of jurisdiction and admissibility, to prevent a case from being investigated or prosecuted. ${ }^{3}$ Considering the importance in the pre-trial level, the interests of justice should be monitored to be inside the boundaries of its regulations. However, the boundaries are unclear. Article 53 does not state specific elements for the term's criteria and definition.

\footnotetext{
CICC, "ICC's Decision on Afghanistan Investigation," https://www.coalitionfortheicc.org/afghanistaninvestigation, accessed on December 2020.

2 HRW, "The Meaning of the 'Interests of Justice' in Article 53 of the Rome Statute" https://www.hrw.org/news/2005/06/01/meaning-interests-justice-article-53-rome-statute\#, accessed on November 2019.

3 Otto Trifterer and Kai Ambos (eds), The Rome Statute of the International Criminal Court: A Commentary, Berlin: CH Publishing House, 2016, p. 1374.
} 
There have been many studies to determine the boundaries of the interests of justice, especially in regards of the elements of the criteria. They mostly focused on the matters of one specific situation rather than to formulate the elements as a whole. ${ }^{4}$ Analysis regarding the criteria's competence, specifically relating to the prosecutorial discretion element it possessed, has also been conducted. However, they lean heavily on the prosecutor's roles and limitations and often left out the PTC's corresponding responsibilities and boundaries. ${ }^{5}$ The invocation of the interests of justice in the Afghanistan case had also been assessed, although matters arising from the $A C$ and perspective or the substantial limits of the PTC's review power were not addressed. ${ }^{6}$

This paper highlights the necessity to delineate and define the concept in the interests of justice'. It focuses on two main issues. The first is the specific limitations to examine the interest of justice under international criminal law, especially regarding perspective, division of authority, and terms of usage. The second is the analysis on the conformity of the interests of justice criteria by both PTC and AC in the Afghanistan with international criminal law.

This paper begins by examining the limits of the scope, authorities, and boundaries of usage relating to the interests of justice. In understanding the criteria's philosophy and nuance, this paper explores the criteria under Article 53 of the Statute by interpreting the original intent, ordinary reading, and their supplementary documents. The Afghanistan case is then compared to the results of these examinations, as well as previous decisions of the PTC regarding the interests of justice, namely the Situations in Burundi (Burundi case), the Situations in Georgia (Georgia case), and the Situations in Kenya (Kenya case) to determine the conformity of the criterion in Afghanistan with the perception of interests of justice in the international criminal law.

As a balancing mechanism, it is imperative to clearly limit the interests of justice regarding the scope and authority to be used properly. The ICC shall regulate the scope and authority of the criteria in accordance with the limits put forth in this paper's examination.

$4 \quad$ Michael Kourabas, "A Vienna Convention Interpretation of the Interests of Justice Provision of the Rome Statute, the Legality of Domestic Amnesty Agreements, and the Situation in Northern Uganda: A Great Qualitative Step forward, or a Normative Retreat", UC Davis Journal of International Law \& Policy, Vol. 14, No. 59, 2007, pp. 69-79.

5 H. M. Lovat, "Delineating the Interests of Justice: Prosecutorial Discretion and the Rome Statute of the International Criminal Law," Bepress Legal Series, 2006, p. 1443.

$6 \quad$ L. P. Rosetti, "The Pre-Trial Chamber's Afghanistan Decision: A Step Too Far in the Judicial Review of Prosecutorial Discretion?", Journal of International Criminal Justice, Vol. 17, No. 3, 2019, p. 605. 


\section{B. Scope and Perspective of the Interests of Justice as a Balancing Mechanism}

In domestic legal systems, a judicial dismissal for interests of justice accounts for non-legal elements that jurisdiction or case adequacy do not factor. ${ }^{7}$ It includes, but is not limited to; the perpetrator's condition and/or degree of accountability, the victim's and/or public interests to the case, as well as its development and gravity. ${ }^{8}$ Since the specific requirements vary in different states, the perspective used to assess this matter usually focuses on the perpetrator's conditions and public interests, specifically those impacted by the case. ${ }^{9}$

The delegation of the United Kingdom (UK) then brought the concept to the drafting table of the Rome Statute. They argued that some cases might have unique situations so that while they fulfill the jurisdiction and admissibility, their investigation and/or prosecution will hinder or not serve justice. ${ }^{10}$ Thus, they need their specific criteria to cover such situations. ${ }^{11}$ The UK's original suggestion of the interests of justice adheres to its common law roots. ${ }^{12}$ It only included situations relating to the accused. For instance, they are very old or ill. ${ }^{13}$ This proposal was expanded so that the criteria could include certain situations, like interests of the victims; age, involvement, and well-being of the perpetrator; and gravity of the crime ${ }^{14}$ These are not fixed criteria, but rather some examples the prosecutor may follow in assessing a case. The Interests of justice were not defined clearly since the drafters never reached a unanimous conclusion. ${ }^{15}$ Instead, they decided to leave the term opened for interpretation, expecting that the criteria may benefit the context of each case. ${ }^{16}$

This section elaborates the interests of justice in the Rome Statute and attempts to determine specific perspective and standard to be used in examining criteria.

\section{The Scope of Interests of Justice Under Article 53 of The Rome Statute}

T. H. Clark, "The Prosecutor of the ICC, Amnesties, and the "Interests of Justice": Striking a Delicate Balance", Washington University Global Studies Law Review, Vol. 4, No. 2, 2005, p. 404.

8 People v. Clayton, 41 A.D.2d 204, Appellate Division of the Supreme Court of New York, April 2, 1973, p. 3.

$9 \quad$ Mohammed Imam, "Power To Prosecute and Enter Nolle Rosequi Under The Federal Constitution and Laws of Malaysia: A Viewpoint," Journal of the Indian Law Institute, Vol. 42, No. 1, 2000, p. 54.; J. J. Mwalili, "The Role and Function of Prosecution in Criminal Justice", 107th International Training Course Participants Papers, Resource Material, No. 53, p. 221.

10 Gilbert Bitti, "Interests of Justice: Where Does It Come From? Part I", https://www.ejiltalk.org/the-interestsof-justice-where-does-that-come-from-part-i/, accessed on July 2020.

11 Drazan Đukic', "Transitional justice and the International Criminal Court - in "the interests of justice"?", International Review of the Red Cross, Vol. 89, No. 867, 2007, p. 695.

12 Gilbert Bitti, "Interests of Justice: Where Does It Come From? Part II", https://www.ejiltalk.org/the-interestsof-justice-where-does-that-come-from-part-ii, accessed on July 2020.

13 UK Discussion Paper on the Drafting for the Statute of the International Criminal Court, 1990, para. 31.

14 Articles $53(1)(c), 53$ (2)(c) of the Rome Statute of the International Criminal Court (Rome Statute).

15 Anna Macdonald, ''In the interests of justice?' The International Criminal Court, Peace Talks and the Failed Quest for War Crimes Accountability in Northern Uganda", Journal of Eastern African Studies, Vol. 11, No. 4, 2017, pp. 628-648.

16 Maria Varaki, "Revisiting the Interests of Justice' Policy Paper", Journal of International Criminal Justice, Vol. 15, No. 3, 2017, pp. 455-470. 
Article 53 of the Statute mentions the 'interest of victims', the 'age or infirmity', and role of the perpetrator as parts of the circumstances that can be considered for the interests of justice. The term is used often to refer factors, circumstances, and developments. They can determine the victim's interests to be handled by the ICC. ${ }^{17}$ The perpetrator's condition is also considered to protect his/her rights before the ICC and to ensure a fair trial. ${ }^{18}$

The Statute's objective and purpose supports the relation between the interests of justice and the interests of victims. ${ }^{19}$ It acknowledges the crisis of impunity that worsened the crimes perpetrated, causing endless suffering to the civilian population falling victims to it. ${ }^{20}$ The ICC also aims to punish atrocious crimes $^{21}$ mainly for the victims' interests. ${ }^{22}$ In the Rome Conference of June and July 1998, many parties discussed the Statute's object and purposes. ${ }^{23}$ Several members of UN General Assembly expressed that "the interest of justice would be served if victims could also be made parties to the trial." 24

There were little discussions on the perspective of 'conditions of the alleged perpetrator' under the interests of justice in Article 53 of the Statute. The perspective is equally in line with the international criminal law objective for a fair trial that protects the rights of the accused. ${ }^{25}$ The fact that the interests of justice criteria were also initiated due to concerns regarding the exceptional conditions of the alleged perpetrator ${ }^{26}$ also emphasizes the important of the perspective to determine interests of justice within a case.

The concept of interests of justice was designed to fulfill extraordinary and/or legally unpredictable situations that needs broader scope. ${ }^{27}$ However, in providing evidences and reasoning, the prosecutor may not create mere arbitrary determination to avoid an investigation, hence the imposition of the standard 'substantial reasons to believe' towards the criteria. ${ }^{28}$ Compared to 'reasonable

17 Otto Trifterer and Kai Ambos, op.cit., p. 1374.

18 K. Kremens, "The Protection of the Accused in International Criminal Law According the Human Rights Law Standard," Wroclaw Review of Law, Administration, \& Economics, Vol. 1, No. 2, 2011, p. 27.

19 Preamble para. 2 of the Rome Statute.

20 Preamble para. 4 of the Rome Statute.

21 Mark Klamberg, Commentary on the Law of the International Criminal Court, Brussels: Torkel Opsahl EPublisher, 2017, p. 1; Richard J. Goldstone and Nicole Fritz, "In the Interests of Justice' and Independent Referral: The ICC Prosecutor's Unprecedented Powers," Leiden Journal of International Law, Vol. 13, pp. 655667.

22 Luke Moffet, Justice for Victims before the International Criminal Court, New York: Routledge Publishing, 2014, p. 24

23 Darryl Robinson, "Defining "Crimes Against Humanity" at the Rome Conference", The American Journal of International Law, Vol. 93, No. 1, 1999, p. 43.

24 United Nations Diplomatic Conference of Plenipotentiaries on the Establishment of an International Criminal Court, Vol. II, Rome, 15 June -17 July 1998 (Rome Conferences, Vol. II), p. 99.

25 Rome Conferences, Vol. II, p. 76.

26 UK Discussion Paper, op.cit.

27 Stephano Bibas, "The Need for Prosecutorial Discretion", Temple Political and Civil Rights Law Review, Vol. 19, No. 2, 2010, p. 371.

28 Otto Trifterer and Kai Ambos, op.cit., p. 1374. 
basis to believe' of jurisdiction and admissibility, the 'substantial reasons to believe' demands that the prosecutor must provide evidence relating to either scale, nature, manner of commission, and impacts of crimes. ${ }^{29}$ However, since the interests of justice discusses about possible outcomes when a case is investigated, in determining the criteria, the prosecutor must also devise a reasonable argument that the possibility of the situation happening is more than likely based on the evidences they had provided. Thus, it is quite clear that the threshold put on the 'interests of justice' criteria is slightly higher than that of the court jurisdiction and case admissibility.

\section{Possibility for Other Elements to the Criteria of the Article 53 in the Prosecutor's Policy Papers}

Prosecutors traditionally assess interests of justice in line with Article 53. They can consider circumstances that are not included in the Statute. ${ }^{30}$ These alternatives are mentioned in several Policy Papers of Prosecutor, which does not legally bind the ICC, ${ }^{31}$ but provides further insight to the incumbent prosecutor's perspective in assessing the criteria. ${ }^{32}$

The 2007 Policy Paper mentioned 'other justice mechanisms' and 'peace processes' as alternative circumstances to determine interests of justice. ${ }^{33}$ In considering the first, the Policy Paper argues that while the pursuit of criminal justice through the ICC as the norm when International Criminal Law is concerned. ${ }^{34}$ There are possibilities that other complementary roles may achieve a broader and more comprehensive justice that would benefit the parties involved and the international community. ${ }^{35}$ In considering a 'peace process', the Policy Paper established that in special circumstances, achieving justice does not equate establishing peace, and certain legal action may be deferred in maintaining peace and stability. ${ }^{36}$ This deference is to reach a broader justice and peace unable to be fulfilled by traditional prosecution process. ${ }^{37}$

Similarly, according to the 2003 Draft Regulations of the Office of the Prosecutor, if the drafters is authorized to determine the elements for the interests

29 M.M.M. deGuzman, "Choosing to Prosecute: Expressive Selection at the International Criminal Court," Michigan Journal of International Law, Vol. 33, 2012, p. 293.

$30 \quad$ Otto Trifterer and Kai Ambos, op.cit., p. 1374.

31 International Criminal Court, "Policies and Strategies," https://www.icc-cpi.int/about/otp/Pages/otppolicies.aspx, accessed on July 2020.

32 Carsten Stahn, "Complementarity, Amnesties and Alternative Forms of Justice: Some Interpretative Guidelines for the International Criminal Court", Journal of International Criminal Justice, Vol. 3, No. 3, 2005, pp. 695-720.

33 Office of the Prosecutor, Policy Paper on the Interests of Justice, September 2007 (PP. Interests of Justice), p. 9.

$34 \quad$ PP. Interests of Justice, p. 7.

35 Office of the Prosecutor, "Paper on Some Policy No. 5 before the Office of the Prosecutor", September 2003 (PP 2003), p. 3.

36 PP. Interests of Justice, p. 8.

37 Rome Conferences, Vol. II, p. 273. 
of justice, then it would be (1) the start of an investigation would worsen a conflict situation; (2) the start of an investigation would seriously endanger the successful completion of a reconciliation or peace process; or (3) the start of an investigation would bring the law into disrepute. ${ }^{38}$ The finalized version omits these considerations. However, the overall analysis on the prosecutor's view on interest of justice is similar to the 2007 Policy Paper. It emphasizes the prosecution effect to the stability of the situation, and the prosecution compared to a more beneficial justice and/or peace mechanism.

This study agrees that the interests of justice should be able to fulfill non-legal elements that might be overlooked by jurisdiction and admissibility. However, it is within the opinion that the interests of justice still exist with limitations. Although not explicitly mentioned, Article 53 demands assessment of interests of justice in the perspective of 'interests of the victims' and 'conditions of the alleged perpetrator'. The elements are considered under this perspective are also limited to measureable and fixed aspects in order to satisfy the standards of 'substantial reasons to believe' and to ensure that the elements used to measure the criteria will not undergo fundamental changes in the foreseeable future. In order to ensure a better understanding of the criteria, such limitations must be highlighted and emphasized to prevent misinterpretations. Thus, the criteria must be at least given general borders to properly function.

\section{The Evocation of the Interests of Justice: When and Who Authorizes}

Some domestic legal systems appoint the Prosecutor as the primary filter of the court to maintain efficacy, ${ }^{39}$ allowing the prosecutor to filter cases to be or not to be prosecuted. ${ }^{40}$ Prosecutor's decision not to prosecute includes reasons of public interest, such as threats to peace and order. ${ }^{41}$ This filtering power is used as the court's tool to maintain credibility, ${ }^{42}$ and the prosecutor's decision is indisputable by the court as a judicial branch.

The prosecutorial discretion is included to the Rome Statute but it differs from its domestic origins. In its finalized version, the prosecutorial discretion in the ICC vests the prosecutor powers to initiate an investigation through proprio motu ${ }^{43}$ and to decide in nolle prosequi through Article 53, especially the interests of justice criteria. ${ }^{44}$ However, this determining power is still a subject of review for the PTC Judges. The negative determination of the prosecutor regarding the interests of justice is considered invalid if the judges disagree.

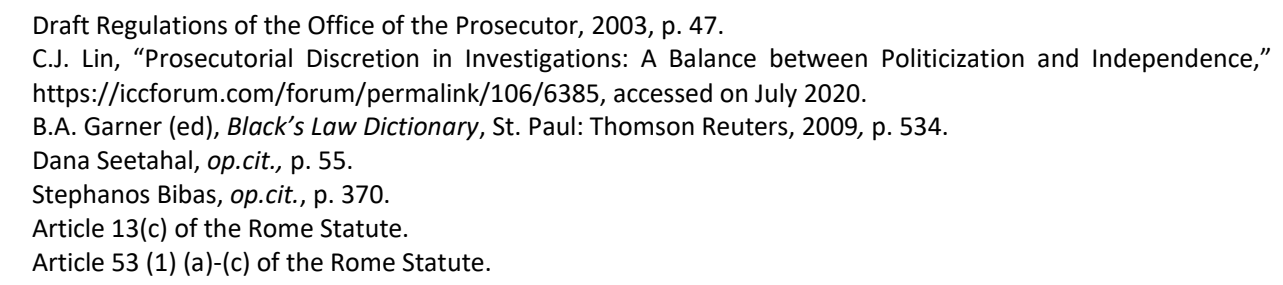


This section examines the extend of the authorities for both the Prosecutor and the PTC of the ICC. It seeks to draw the limits where the two powers meet, and what action can be classified as exceeding authorities.

\section{The Prosecutor's and the PTC's Authority Under the ICC's Regime}

In drafting the Statute, the concept of prosecutorial discretion was proposed to illustrate an intervention-free process, unlike mechanisms such as state or UNSC referrals. ${ }^{45}$ The prosecutor's decision regarding a case is free and independent, in line with the Statute's object and purpose. ${ }^{46}$ However, this power is modified from its traditional domestic design to fit the needs of the ICC as an international criminal judiciary body. Unlike its domestic origins, which disallow any judicial intervention from the judges, the Statute obliges the Prosecutor to report findings to the PTC following a negative determination of the interests of justice criteria. ${ }^{47}$ The PTC then may review such determination-whether on its own volition or through the request of the prosecutor ${ }^{48}$-and, if they evoke the review power, the prosecutor's assessment is only legally binding with the PTC's affirmation. ${ }^{49}$ Thus, such review is not mandatory for the PTC but rather depends on their willingness.

Rule 109 of the Statute's Rules of Procedures and Evidence (ROPE) stipulates that a review under the PTC's independent initiation may occur following a notification not to investigate or prosecute under Rule 105 or $106 . .^{50}$ In Rule 105, notification is required when a negative determination regarding the interests of justice has been made. ${ }^{51}$ Then, the PTC may enact the power to review. ${ }^{52}$

These are procedural compromise for the vagueness of the criteria. The negative determination of the interests of justice in a case is an extraordinary circumstance. Its evocation must be reviewed to prevent misuse. ${ }^{53}$ This procedural compromise offers a check-and-balance mechanism, ensuring limitations on the prosecutor's power to prevent abuse when the subject matter of the interests of justice fails to set specific definition or scope. ${ }^{54}$

The Statute and ROPE share similarities regarding the technical boundaries between the prosecutor's and the PTC's authority to the interests of justice. However, the 2007 Policy Paper assigns them differently. It argues that the check-

\footnotetext{
45 A.M. Danner, "Enhancing the Legitimacy and Accountability of Prosecutorial Discretion at The International Criminal Court", American Journal of International Law, Vol. 97, 2003, pp. 513-514.

46 See Preamble of the Rome Statute.

$47 \quad$ Article 53 (1) (c) and (2) (c) of the Rome Statute.

48 Article $53(3)(b)$ of the Rome Statute.

$49 \quad$ Ibid.

50 Rules 105 (4) and 106 (1) of the Rules of Procedures and Evidence, 2002 (ROPE).

51 Karel De Meester, "Commentary of Rules of Procedures and Evidence," https://www.casematrixnetwork.org/cmn-knowledge-hub/icc-commentary-clicc/commentary-rules-ofprocedure-and-evidence/commentary-rpe-ch-5.html, accessed on 25 July 2020.

52 Decision Pursuant to Article 15 of the Rome Statute on the Authorization of an Investigation into the Situation in the Republic of Kenya, ICC-01/09, PTC II, 31 March 2010 (Kenya Decision), p. 27.

$53 \quad$ PP. Interests of Justice, p. 8.

54 Gilbert Bitti, "Part II.", op.cit.
} 
and-balance should be conducted regardless of the final determination of the interests of justice criteria to ensure fair assessment. ${ }^{55}$

In conducting such review, The PTC is still expected to re-examine the interests of justice criteria under the same parameters as in the Prosecutor's brief. ${ }^{56}$ No discussions as to the circumstances where the PTC decides to review the interests of justice using parameters independent of the prosecutor's brief. However, the PTC has the privilege to request for an additional evidence and/or observations to the Prosecutor and the victim's councils prior to coming to a decision. ${ }^{57}$

\section{Can The Interest of Justice Be Evoked For Proprio-Motu Initiated Cases?}

Article 53 of the Statute mentions that UNSC or a State referring to Article 13 or 14 of the Statute may request the PTC to examine the Prosecutor's decision to deny investigation or prosecution under the elements of Article 53. ${ }^{58}$ However, it does not mention its applicability to a proprio-motu-initiated case. In fact, the trigger mechanism for the investigation of proprio-motu-cases is mentioned only in Article $15,^{59}$ which only considers factors of jurisdiction and admissibility. ${ }^{60}$

However, there is correlation between Article 53 and proprio-motu-initiated cases. First, there is prosecutor's discretionary power in both Articles 53(1) and 13(c) of the Statute. ${ }^{61}$ Article 53 elaborates that the prosecutor should initiate an investigation after evaluating information made available, referring to articles 13 and $15(1)-(2)$, which elaborates case reference to the ICC through State Party, UNSC, or proprio motu. ${ }^{62}$ This is emphasized in Rule 48 of the ROPE that prosecutor should use requirements of Article 53(1) to consider Article 15(3). ${ }^{63}$ In addition, while Article 15(4) does not specifically mention Article 53, Rule 50 of the ROPE states that in granting the prosecutor's investigation request for a case under Article 15, the PTC should issue their decision by reviewing the Prosecutor's request, ${ }^{64}$ including the elements derived from Article 53(1).

The travaux préparatoires also considers Article 53 and Article 15 of the Statute. The drafters intended to establish the same standards in both aforementioned articles and wanted to establish a link between them. ${ }^{65}$ This is proven by the commentaries of draft Article 12 of the Statute (the original Article

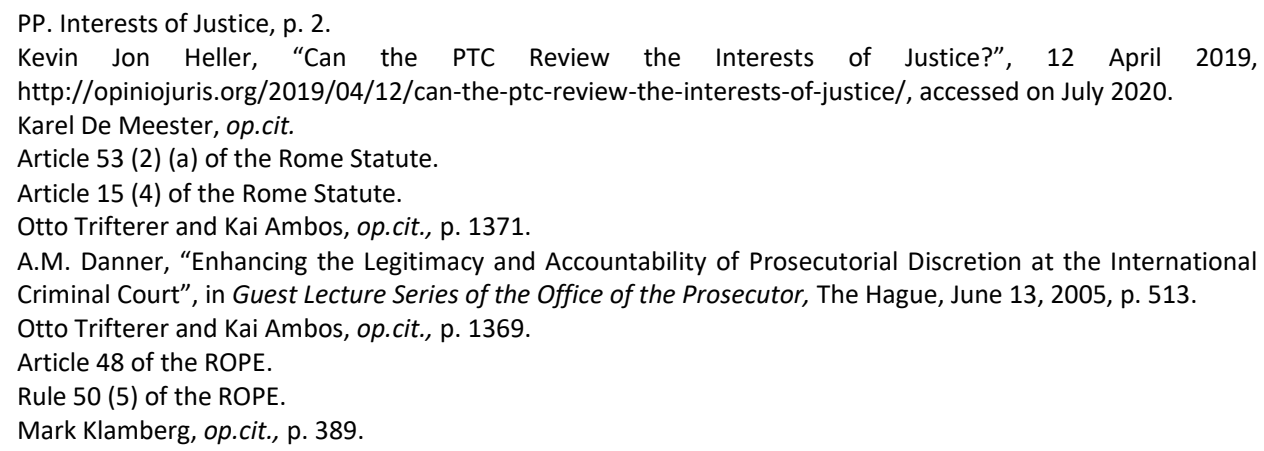


15) that the term 'sufficient basis', if retained in the finalized version, should be harmonized with the term 'reasonable basis to proceed' used on draft Article 54 (the original Article 53). ${ }^{66}$ Similar expressions are also used among the provisions, restating their original intention and the notion that Article 53(1) is the gradual broadening for the criteria enshrined in Article 15(3). ${ }^{67}$ Thus, the study is of the opinion that Article 53(1), including the interests of justice, is actually related to Article 15(3). It should be considered by the PTC's judges in the determination of case to be proceed towards the investigation stage.

\section{The Applications of the Interests of Justice in the ICC: The Case of Afghanistan to the Case of Burundi, Georgia, and Kenya}

In November 2017, the Prosecutor of the ICC filed a request for authorization of an investigation regarding the Afghanistan case. They argued that they had fulfilled the requirement for jurisdiction and admissibility and their investigation was within the interests of justice. ${ }^{68}$ The PTC denied the request since the case's investigation would be against the interests of justice. ${ }^{69}$ The dissatisfied prosecutor appealed. Subsequently, the AC overturns the PTC's decision on March 4, 2020. This allows the Prosecutor to proceed with the investigation they sought. ${ }^{70}$ However, the usage of the interests of justice criteria in these two decisions contrast the ICC's previous decisions regarding the same matter, namely the Kenya, Georgia, and the Burundi cases. To determine whether the 'interests of justice' in the Afghanistan case was used properly, the Afghanistan case shall be examined in the light of our previous assessments and compare it with the three aforementioned cases.

\section{The PTC's Decision on the Afghanistan Case}

The Afghanistan Case is the first case to finalize a decision not to proceed an investigation of a case based on the negative determination of the interests of justice. The Prosecutor argued that the case fulfilled all criteria under Article 53, namely Jurisdiction, admissibility ${ }^{71}$, and the interests of justice, noting the overwhelmingly positive response from victims at the prospect of a trial, and

66 Report of the Preparatory Committee on the Establishment of an International Criminal Court, Addendum: Draft Statute for the International Criminal Court and Draft Final Act of the United Nations Diplomatic Conference of Plenipotentiaries on the establishment of an International Criminal Court, U.N. Doc. A/CONF.183/2/Add.1, 14 April 1998, p. 37.

67 Chris Gallavin, "Article 53 of the Rome Statute of the International Criminal Court: In the Interests of Justice?", King's Law Journal, Vol. 14, No. 2, 2003, p. 185.

68 Public redacted version of "Request for authorization of an investigation pursuant to article 15", ICC-02/17-7Conf-Exp, Office of the Prosecutor for the International Criminal Court (OTP), 20 November 2017 (Afghanistan Request), pp. 22-39; 130-171; 176-179.

69 Decision Pursuant to Article 15 of the Rome Statute on the Authorisation of an Investigation into the Situation in the Islamic Republic of Afghanistan, ICC-02/17, PTC of International Criminal Court (PTC), 21 April 2019 (Afghanistan PTC Decision), p. 31.

70 Judgment on the appeal against the decision on the Authorisation of an investigation into the situation in the Islamic Republic of Afghanistan, ICC-02/17 OA4, AC of the International Criminal Court (AC), 5 March 2020 (Afghanistan AC Decision), p. 21.

71 Afghanistan Request, pp. 22-39; $130-171$. 
adequacy of alleged perpetrators for trial before the ICC. ${ }^{72}$ However, the Judges of the PTC ruled that the case should not proceed into a formal investigation for it would be against the interests of justice, essentially coming to a negative determination of the criteria. ${ }^{73}$

The PTC achieved the negative determination with the absence of a negative determination from the Prosecutor regarding the interests of justice criteria. The PTC used elements unmentioned by the Prosecutor. These elements (limited funding and resources, duration of time elapsed since the initiation of the case, lack of preserved evidences for crimes dating back to 2005, and the probability of little to no cooperation from the parties involved ${ }^{74}$ ) are also not outlined in Article $53(1)(c)$ of the Statute or any other legal framework of the ICC. The PTC argued that these factors could lead to the discontinuation of the case, which would dissatisfy the victim's interests for a prosecution.

There were some speculations that the decision was political. The ICC had an increasingly bad relationship with the government of United States of America, as there are possibilities for them to be investigated in the Afghanistan Case. ${ }^{75}$ Their credibility is in jeopardy due to the cessation of the investigation of the Kenya case and the discontinuation of the prosecutions of Uhuru Muigai Kenyatta. ${ }^{76}$ There are similar elements existing between the Kenya case and the Afghanistan case, namely the difficulties in cooperation with the stakeholders of the case, and the lack of preserved evidence. Thus, if the Afghanistan case suffer the same fate as the Kenya case and be discontinued, it would be a blow to the international community's perspective on the ICC's capacity to properly adjudicate humanitarian violations.

Considering this Decision in comparison with the previous cases handled by the PTC, we can utilize the previous section's conclusions to test whether the PTC Decisions on the Afghanistan case is in line with the elements of the interests of justice.

\section{a. Did PTC Make an Arbitrary Assessment?}

The reasonings for the interests of justice provided in the decision for Afghanistan case are different from the previous decisions regarding similar matters. In the Georgia and Burundi cases, the Prosecutor assessed and concluded that an investigation of the case would serve the interests of justice, emphasizing the

\footnotetext{
Afghanistan Request, pp. $176-179$.

Afghanistan PTC Decision, p. 32.

Afghanistan PTC Decision, p. 30.

HRW, "US Sets Sanctions Against International Criminal Court: Trump Executive Order Seeks to Thwart Justice for Victim", https://www.hrw.org/news/2020/06/11/us-sets-sanctions-against-international-criminal-court, accessed on August 2020.

76 Andrew Tucker \& Gabriele Kuchenbecker, "International Criminal Court Afghanistan Decision - What Are The Implications For Israel/Palestine?”, https://www.thinc.info/international-criminal-court-afghanistan-decisionwhat-are-the-implications-for-israel-palestine/, accessed on August 2020.
} 
victim representative's overwhelming agreement to the investigation. ${ }^{77}$ The 'interests of victims' were strictly limited to the victims' opinions regarding whether should there be an investigation to the cases in question. ${ }^{78}$

The Kenya case also considered the interests of justice in the same vein as the cases of Burundi and Georgia. However, in its development, the case suffers from lack of cooperation from the relevant states and the ICC's constricting budget. ${ }^{79}$ It resulted in the withdrawal of the ongoing prosecution against some of the perpetrators. ${ }^{80}$ The Prosecutor requested cessation of investigations in parts of the case. ${ }^{81}$ In the Kenya case, the PTC states that the cessation of the investigation had nothing to do with any of the Prosecutor's assessment towards the criteria mentioned in Article 53 (1) of the Statute, including the interests of justice. Instead, it reaffirms the Prosecutor's argument that such decision is a very last-resort mechanism based on an unprecedented objective circumstance of temporary nature that can change. Although the investigation is currently discontinued, it is not permanently stopped. The PTC is monitoring the situation for any possible development. ${ }^{82}$

Compared to the Afghanistan case, it can be inferred that the PTC have failed to uphold a consistent argument when it decided that an investigation is against the interests of justice. The PTC did not explain the rationale to state that it would lead to the permanent and irreversible damage to justice if an investigation were initiated. ${ }^{83}$ Further, the PTC argued that these factors would inevitably lead to dissatisfaction of victim's interests. The high possibility of a discontinued case ${ }^{84}$ is believed to be against the interests of victims under Article 53 of the Statute. The PTC's arguments focused more on what the victims will probably perceive in the future rather than what their current perceptions are.

Such reasoning does not fulfill the standards of the interests of justice. As mentioned above, the standard 'substantial reasons to believe' focuses on measurable elements of the criteria; the possibility for the dissatisfaction of the

77 Decision on the Prosecutor's request for Authorization of An Investigation, ICC-01/15, PTC I, 27 January 2016 (Georgia Decision), p. 23; Public Redacted Version of "Decision Pursuant to Article 15 of the Rome Statute on the Authorization of an Investigation into the Situation in the Republic of Burundi" ICC-01/17-X-9-US-Exp, PTC III, 25 October 2017 (Burundi Decision), p. 91.

78 Kenya Decision, p. 13; Georgia Decision, p. 24; Burundi Decision, p. 92.

79 Kirsten Ainley, "Retreat or Retrenchment? An Analysis of The International Criminal Court's Failure to Prosecute Presidents," in Brysk, Alison and Stohl, Michael (eds.), Contracting Human Rights: Crisis, Accountability, and Opportunity, Cheltenham, UK: Edward Elgar, 2017, p. 2.

80 Decision on the Withdrawal of Charges Against Mr. Muthaura, ICC-01/09-02/11-696, Trial Chamber V, 18 March 2013; Decision on the withdrawal of charges against Mr. Kenyatta, ICC-01/09-02/11-1005, Trial Chamber V(B), 13 March 2015.

81 Prosecution's Application to Dismiss in Limine the Victims' Request for Review of Prosecution's Decision to Cease Active Investigation, ICC-01/09-154-Conf-Anx2, Office of the Prosecutor, 25 August 2015.

82 Decision on the "Victims' Request for Review of Prosecution's Decision to Cease Active Investigation", ICC01/09, PTC II, 5 November 2015, p. 25.

83 Andrea Carcano, "On the Exercise of the Judicial Function at the International Criminal Court: No. 5 of Credibility and Structural Design", QIL Zoom-In, Vol. 67, 2020, p. 10.

84 Afghanistan PTC Decision, p. 31. 
victim's interests in the future is too abstract to concretize. Additionally, as seen in the Kenya case, lack of cooperation and incriminating evidence can only temporarily cease, instead of permanently stopping, such investigation, for such are prone to regime and policy developments. ${ }^{85}$ Predictions to the effect of these situations are uncertain, meaning that the decision could become heavily arbitrary and even veer to political interests. ${ }^{86}$ It is strictly prohibited in the standards of the criteria. ${ }^{87}$

\section{b. The PTC's Power to Review the Interests of Justice: an Act of Ultra Petita and Ultra Vires}

In the Afghanistan case, the PTC came to a negative determination for the interests of justice criteria after the Prosecutor had already determined that the investigation would not be against the interests of justice, using situations outside the Prosecutor's submission. ${ }^{88}$ Furthermore, the PTC delivered such determination directly in a decision, without prior consultation with or observation from the prosecutor or the victim's council regarding the elements it uses to measure the aforementioned criteria, thus violating the due process requirements. ${ }^{89}$

Furthermore, the PTC's interpretation regarding the Judges' authority in relation to the interests of justice is different with the PTC's previous Decisions. In the Kenya case, the PTC did not review a positive determination of the interests of justice criteria since it is the normal expectation of the assessment. These were also no problem in the Burundi and Georgia cases. There are several reasons to conclude that the sequence of actions by the PTC Judges in the Afghanistan case is a massive overstep of their authority. Not only were they exercising their power to review the criteria without the existence of the proper trigger mechanism, they also reviewed the criteria using elements that are not included in the prosecutor's brief. Additionally, the PTC's lack of consultation with the victims in making its assessment also implies that they were not involved in a matter that is supposed to be part of their interests. ${ }^{90}$ Knowing it is not mandatory, the Prosecutor consistently uses the voices of the victims to determine the presence of the interests of justice within a case. The study is within the opinion that the PTC is

85 Geoff Dancy and Florencia Montal, "Unintended Positive Complementarity: Why International Criminal Court Investigations May Increase Domestic Human Rights Prosecutions", American Journal of International Law, Vol. 111, 2017, p. 689.

$86 \quad$ Andrea Carcano, op.cit., p. 12.

87 10(2) of Code of Judicial Ethics, 2005.

88 Public redacted version of "Request for Authorisation of An Investigation Pursuant To Article 15", ICC-02/17-7Conf-Exp, Office of the Prosecutor, 20 November 2017, pp. 177 - 178.

89 Moffett L. Dempster (et.al), “Observations by Queen's University Belfast Human Rights Centre as Amicus Curiae On The Appeal of PTC II's 'Decision Pursuant to Article 15 of the Rome Statute on the Authorisation of an Investigation into the Situation in the Islamic Republic of Afghanistan' of 12 April 2019," Queen University Belfast-Research Portal, November 2019, p. 10.

90 Amicus Curiae Observations Pursuant to Rule 103 of the Rules of Procedure and Evidence, ICC-02/17, PTC II (PTC), 11 July 2019, p. 21. 
ethically expected to do the same, especially in determining whether the situations listed would dis/satisfy the victims.

The PTC made a harmful precedent in passing such decision, where the criteria may be decided one-sidedly by the PTC, thus omits the check-and-balance procedure, and jeopardizes the ICC's credibility.

\section{The AC's Decision on the Afghanistan case: Misinterpretation of the Interest of Justice for Proprio-Motu Initiated Case}

The AC's Decision to overturn the PTC's decision on the Afghanistan case highlighted that the interests of justice should only be a determining factor in cases that are brought forth through the UNSC or a state party's request. It is not a requirement requiring assessment by the Prosecutor and/or review by the PTC when it is a proprio motu case. ${ }^{91}$ While the AC did acknowledge the link between Articles 15(3) and 53(1) stipulated in Rule 48 of the ROPE, it assessed that such is only applicable to the Prosecutor when they were considering the elements of a case and does not bind the PTC's judgement. Rather, they argued that the PTC should reach its own determination under 15(4) since the aforementioned article does not specifically call to review the Prosecutor's analysis for the factors laid out under Article 53(1) of the Statute. Simply put, they were of the view that in examining cases originating from proprio motu, The PTC should no longer consider the interests of justice as part of its determinant in granting an investigation.

Interestingly, previous cases mentioning the interests of justice are cases that are initiated by proprio motu. In the Kenya case, the PTC elaborated the relation between criteria in Articles 53 (1) and 15 (3). Thus, all of its requirements, including the criteria for the interests of justice, should be included in the Prosecutor's assessment when initiating a proprio motu case ${ }^{92}$ in accordance with Rule 48 of the ROPE. ${ }^{93}$ The ICC established that it would be illogical to consider the standards in Articles 15(3) and 53(1) as separate, dissociated entities. ${ }^{94}$ It further established that these articles should be considered simultaneously due to its language and purpose similarities, which is to open an investigation to a potential case brought before the ICC. ${ }^{95}$ Thus, previous decisions posit that Article 53(1) is applicable to cases that are initiated by proprio motu. It separates Articles 15(3) and 53(1) in the judgment of the case's adequacy under investigation is not possible.

Such omission would hinder the wholeness of the case's assessments. The balanced application of the interests of justice is what proprio motu-initiated cases need. The Prosecutor initiating cases on their own needs their assessment towards

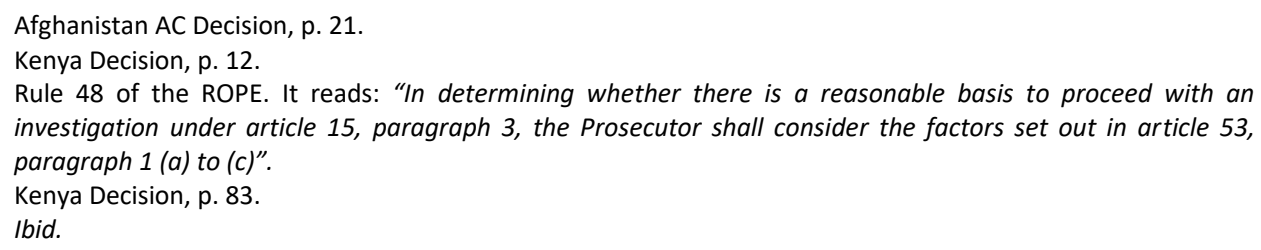


the proposed case to be reviewed by the PTC. The PTC should request the Prosecutor for additional evidences for circumstances that the Prosecutor might have overlooked in their initial assessment before deciding. This continuous checkand-balance mechanism could provide transparency on proprio motu cases, which can further legitimize the credibility of the ICC. The statement that the interests of justice is no longer necessary in cases proprio motu could impair the legitimacy of the case for removing one of the only outlets that could consider the interests not fulfilled by conventional legal provisions.

\section{E. Conclusions}

The ICC does not only prevent impunity ${ }^{96}$ but it also maintains peace and security of the world. ${ }^{97}$ This reflects the juxtaposition in the ICC's scope of justice; retributive justice (relying on penalization and culpability) and restorative justice (relying on the accountability and the relationship among offenders, victims and their communities). ${ }^{98}$ Despite the fact that the ICC fulfills retributive justice in most of its provisions, it also provides for restorative justice to ensure that its decision does not jeopardize and overlook the interests of victims and communities directly impacted by the crimes. ${ }^{99}$ The ICC continues to strive for the balance for these two types of justice to encapsulate justice entirely. The attention put to restorative justice can be seen in the interests of justice criteria enshrined in Article 53, specifically in a comparison with 'jurisdiction' and 'case admissibility' criteria as the elements of retributive justice. ${ }^{100}$

The interests of justice emphasize judgement on a case-by-case basis, taking into account of 'all circumstances', including those jurisdiction and admissibility might not cover ${ }^{101}$ such as the interests of victims, and circumstances of the offenders. This accommodates unique circumstances that might be overlooked without the existence of such criteria. However, it is also due to its abstract nature that a limit should exist for the criteria to prevent producing an arbitrary determination. Analysis shows that limitations exist through the perspective and standard used to assess the criteria. The existence of such balance allows more nuance to be considered in a case, without threatening the assessment to be accused as arbitrary or politically charged. The division of authority and power between the Prosecutor and the PTC based on Article 53(3)(b) should also be noted as part of the balancing mechanism of the interests of justice criteria since it

\footnotetext{
Preamble, para. 11 of the Rome Statute.

Preamble, para. 3 of the Rome Statute.

Bartłomiej Krzan, "International Criminal Court Facing the Peace vs. Justice Dilemma", International Comparative Jurisprudence, Vol. 2, 2016, p. 82.

99 Catherine Gegout, "The International Criminal Court: Limits, Potential and Conditions for the Promotion of Justice and Peace", Third World Quarterly, Vol. 34, No. 5, 2013, p. 803.

100 Alexander K.A. Greenwalt, "International Criminal Law for Retributivists", U. Pa. Journal of International Law, Vol. 35, No. 4, 2014, p. 974.

101 Mark Klamberg, op.cit., p. 393; Otto Trifterer and Kai Ambos, op.cit., p. 1367.
} 
creates a strict and clear check-and-balance mechanism for the criteria to be assessed.

The Afghanistan case is an example of the misunderstanding of these limits and balancing nature. For the PTC, the one-sided decision of the criteria removes the balancing function and element of the interests of justice. The fact that it is concluded with rather inadequate reasoning based on the determination of temporary circumstances creates a narrative that may be perceived as political interests in its application, which is against the Code and Purpose of the ICC and the essence of the criteria. On the other hand, the AC's opinion that the Prosecutor should not review a proprio motu-initiated case under Article 53(1) is contradictory to the essence of Article 15(4) of the Statute and Rule 50(5) of the ROPE. The PTS should have argued that it raises a new concern previously not considered by the Prosecutor in their Request to Investigate. Then, the PTC should have requested for an additional evidence to the prosecutor instead of single-handedly assess and decide on the matter.

This study suggests a comprehensive check-and-balance mechanism for the PTC in deciding a negative determination for the criteria of the interests of justice. It is to ensure transparency and prevention of arbitrary decision in applying the criteria. Further, this study also suggests the ICC to produce a guidebook on the perspective that should be used by the Prosecutors and the PTC to interpret the criteria, as well as making an explicit elaboration on the elements for the standard of 'substantial reasons to believe,' in accordance to the assessments of this study.

\section{References}

\section{Books}

Ainley, Kirsten, "Retreat or Retrenchment? An Analysis Of The International Criminal Court's Failure To Prosecute Presidents", in Brysk, Alison and Stohl, Michael, (eds.) Contracting Human Rights: Crisis, Accountability, and Opportunity, Edward Elgar, Cheltenham, UK, 2017.

Garner, B.A. (ed), Black's Law Dictionary, Thomson Reuters, St. Paul, 2009.

Klamberg, Mark, Commentary on the Law of the International Criminal Court, Torkel Opsahl E-Publisher, Brussels, 2017.

Ligeti, K, the Place of the Prosecutor in Common Law and Civil Law Jurisdictions, in the Oxford Handbook of Criminal Process, Oxford University Press, Oxford, 2019.

Moffet, Luke, Justice for Victims before the International Criminal Court, Routledge Publishing, New York, 2014.

Seetahal, Dana, Commonwealth Caribbean Criminal Practice and Procedure, Cavendish Publishing, New York, 2001.

Trifterer, Otto and Kai Ambos (eds), The Rome Statute of the International Criminal Court: A Commentary, CH Publishing House, Berlin, 2016. 


\section{Other Documents}

Bibas, Stephano, "The Need for Prosecutorial Discretion", Temple Political and Civil Rights Law Review, Vol. 19, No. 2, 2010.

Bitti, Gilbert, "Interests of Justice: Where Does It Come From? Part II" https://www.ejiltalk.org/the-interests-of-justice-where-does-that-come-frompart-ii/.

Brown, D. K., "How Criminal Law Dictates Rules of Prosecutorial Authority," https://law.rutgers.edu/sites/law/files/attachments/Brown\%20-

\%20How\%20Criminal\%20Law\%20Dictates\%20Rules\%20of\%20Prosecutorial\%20 Authority.pdf.

Carcano, Andrea, "On the Exercise of the Judicial Function at the International Criminal Court: No. 5 of Credibility and Structural Design," QIL Zoom-In, Vol. 67, 2020.

Clark, T. H.,"The Prosecutor of the ICC, Amnesties, and the "Interests of Justice": Striking A Delicate Balance," Washington University Global Studies Law Review, Vol. 4, No. 2, 2005.

Coalition for the International Criminal Court, "ICC's Decision on Afghanistan Investigation", https://www.Coalitionfortheicc.Org/Afghanistan-Investigation.

Dancy, Geoff and Florencia Montal, "Unintended Positive Complementarity: Why International Criminal Court Investigations May Increase Domestic Human Rights Prosecutions", American Journal of International Law, Vol. 111, 2017.

Danner, A. M., "Enhancing The Legitimacy And Accountability of Prosecutorial Discretion At The International Criminal Court", American Journal of International Law, Vol. 97, 2003.

De Meester, Karel, "Commentary of Rules of Procedures and Evidence", https://Www.Casematrixnetwork.Org/Cmn-Knowledge-Hub/Icc-CommentaryClicc/Commentary-Rules-Of-Procedure-And-Evidence/Commentary-Rpe-Ch5.html.

Deguzman, M. M., "Choosing To Prosecute: Expressive Selection at The International Criminal Court", Michigan Journal of International Law, Vol. 33, 2012.

Dempster, Moffett L. (et.al), “Observations by Queen's University Belfast Human Rights Centre As Amicus Curiae on The Appeal Of PTC II's 'Decision Pursuant To Article 15 of The Rome Statute on The Authorisation of An Investigation Into The Situation In The Islamic Republic Of Afghanistan' Of 12 April 2019", Queen University Belfast - Research Portal, November 2019.

Dong, J., "Prosecutorial Discretion at the International Criminal Court: A Comparative Study", Journal of Politics and Law, Vol. 2, No. 2, June 2009.

Đukic, Drazan", "Transitional Justice and the International Criminal Court - In "the Interests of Justice"?", International Review of the Red Cross, Vol. 89, No. 867, 2007. 
Gallavin, Chris, "Article 53 Of The Rome Statute Of The International Criminal Court: In The Interests of Justice?", King's Law Journal, Vol. 14, No. 2, 2003.

Gegout, Catherine, "The International Criminal Court: Limits, Potential and Conditions for the Promotion of Justice and Peace", Third World Quarterly, Vol. 34, No. 5, 2013.

Goldstone, R. J. and Nicole Fritz, "In the Interests of Justice' and Independent Referral: The ICC Prosecutor's Unprecedented Powers", Leiden Journal of International Law, Vol. 13, No. 3, 2000.

Greenwalt, Alexander K. A., "International Criminal Law for Retributivists", U. Pa. Journal of International Law, Vol. 35, No. 4, 2014.

Hamilton, James, "Non-Prosecutorial Functions of the Prosecutor in Common Law Countries," in European Conference of Prosecutors 2008, https://www.dppireland.ie/app/uploads/2008/07/Speech_to_European_Confe rence_of_Prosecutors_2_July_2008_PDF.pdf.

Heller, Kevin Jon, "Can the PTC Review the interests of justice?" http://opiniojuris.org/2019/04/12/can-the-ptc-review-the-interests-of-justice/. Human Rights Watch, "The Meaning Of the 'Interests of Justice' in Article 53 of the Rome Statute", https://www.hrw.org/news/2005/06/01/meaning-interestsjustice-article-53-rome-statute\#.

Imam, M., "Power To Prosecute And Enter Nolle Prosequi Under The Federal Constitution And Laws of Malaysia: A Viewpoint", Journal of the Indian Law Institute, Vol. 42, No. 1, 2000.

International Criminal Court, "Policies and Strategies," https://www.icccpi.int/about/otp/Pages/otp-policies.aspx.

"Interests of Justice: Where Does It Come From?

Part I", https://www.ejiltalk.org/the-interests-of-justice-where-does-thatcome-from-part-i/.

Kourabas, M. "A Vienna Convention Interpretation of the Interests of Justice Provision of the Rome Statute, the Legality of Domestic Amnesty Agreements, and the Situation in Northern Uganda: A Great Qualitative Step forward, or a Normative Retreat", UC Davis Journal of International Law \& Policy, Vol. 14, No. 59, 2007.

Kremens, K., "The Protection of the Accused in International Criminal Law According the Human Rights Law Standard," Wroclaw Review of Law, Administration \& Economics, Vol. 1, No. 2, 2011.

Krzan, Bartłomiej, "International Criminal Court Facing the Peace vs. Justice Dilemma," International Comparative Jurisprudence, Vol. 2, 2016.

Lin, C. J., "Prosecutorial Discretion in Investigations: A Balance between Politicization and https://iccforum.com/forum/permalink/106/6385.

Lovat, H. M., "Delineating the Interests of Justice: Prosecutorial Discretion and the Rome Statute of the International Criminal Law", Bepress Legal Series, 2006. 
Macdonald, Anna, "'In the Interests of Justice?' The International Criminal Court, Peace Talks and the Failed Quest for War Crimes Accountability in Northern Uganda", Journal of Eastern African Studies, Vol. 11, No. 4, 2017.

Mwalili, J. J., "The Role and Function of Prosecution in Criminal Justice", 107th International Training Course Participants Papers, Resource Material No. 53.

Robinson, Darryl, "Defining "Crimes against Humanity" at the Rome Conference", The American Journal of International Law, Vol. 93, No. 1, 1999.

Rosetti, L. P., "The Pre-Trial Chamber's Afghanistan Decision: A Step Too Far in the Judicial Review of Prosecutorial Discretion?", Journal of International Criminal Justice, Vol. 17, No. 3, 2019.

Stahn, Carsten, "Complementarity, Amnesties and Alternative Forms of Justice: Some Interpretative Guidelines for the International Criminal Court", Journal of International Criminal Justice, Vol. 3, No. 3, 2005.

Tucker, Andrew \& Gabriele Kuchenbecker, "International Criminal Court Afghanistan Decision - What Are the Implications for Israel/Palestine?" https://www.thinc.info/international-criminal-court-afghanistan-decisionwhat-are-the-implications-for-israel-palestine/.

Varaki, Maria, "Revisiting the Interests of Justice' Policy Paper", Journal of International Criminal Justice, Volume 15, No. 3, 2017.

\section{Legal Documents}

Amicus Curiae Observations Pursuant to Rule 103 of the Rules of Procedure and Evidence, ICC-02/17, PTC II (PTC), 11 July 2019.

Code of Judicial Ethics, 2005.

Decision on the "Victims' request for review of Prosecution's decision to cease active investigation", ICC-01/09, PTC II, 5 November 2015.

Decision on the Prosecutor's request for authorization of an investigation, ICC01/15, PTC I, 27 January 2016.

Decision on the withdrawal of charges against Mr. Muthaura, ICC-01/09-02/11-696, Trial Chamber V, 18 March 2013; Decision on the withdrawal of charges against Mr. Kenyatta, ICC-01/09-02/11-1005, Trial Chamber V(B), 13 March 2015.

Decision Pursuant to Article 15 of the Rome Statute on the Authorization of an Investigation into the Situation in the Republic of Kenya, ICC-01/09, PTC II, 31 March 2010.

Decision Pursuant to Article 15 of the Rome Statute on the Authorization of an Investigation into the Situation in the Islamic Republic of Afghanistan, ICC02/17, PTC of International Criminal Court (PTC), 21 April 2019.

Draft Regulations of the Office of the Prosecutor, 2003.

Judgment on the appeal against the decision on the authorization of an investigation into the situation in the Islamic Republic of Afghanistan, ICC-02/17 OA4, AC of the International Criminal Court (AC), 5 March 2020.

New York Consolidated Laws, Criminal Procedure Law. 
Paper on some policy No. 5 before the Office of the Prosecutor, Office of the Prosecutor, September 2003.

People v. Clayton, 41 A.D.2d 204, Appellate Division of the Supreme Court of New York, 2 April 1973

Policy Paper on the interests of justice, Office of the Prosecutor, September 2007.

Prosecution of Offences Act, 1985.

Prosecution's application to dismiss in limine the Victims' request for review of Prosecution's decision to cease active investigation, ICC-01/09-154-Conf-Anx2, Office of the Prosecutor, 25 August 2015.

Public Redacted Version of "Decision Pursuant to Article 15 of the Rome Statute on the Authorization of an Investigation into the Situation in the Republic of Burundi" ICC-01/17-X-9-US-Exp, PTC III, 25 October 2017.

Public redacted version of "Request for authorisation of an investigation pursuant to article 15", ICC-02/17-7-Conf-Exp, Office of the Prosecutor, 20 November 2017.

Public redacted version of "Request for authorization of an investigation pursuant to article 15", ICC-02/17-7-Conf-Exp, Office of the Prosecutor for the International Criminal Court (OTP), 20 November 2017.

Queensland Consolidated Acts Criminal Code 1899.

Report of the Preparatory Committee on the Establishment of an International Criminal Court, Addendum: Draft Statute for the International Criminal Court and Draft Final Act of the United Nations Diplomatic Conference of Plenipotentiaries on the establishment of an International Criminal Court, U.N. Doc. A/CONF.183/2/Add.1, 14 April 1998

Rome Statute of the International Criminal Court 2002.

Rules of Procedures and Evidence, 2002.

UK Discussion Paper on the drafting for the Statute of the International Criminal Court 1990.

United Nations Diplomatic Conference of Plenipotentiaries on the Establishment of an International Criminal Court, Vol. II, Rome, 15 June -1 7 July 1998

United States v. Cox, 342 F.2d 167, United States Court of Appeals, Fifth Circuit, 1965. 